\title{
PENGARUH PENANAMAN MODAL DALAM NEGERI (PMDN) DAN PENANAMAN MODAL ASING (PMA) TERHADAP PRODUK DOMESTIK REGIONAL BRUTO (PDRB) SUMATERA UTARA TAHUN 2000-2018
}

\author{
Dede Ruslan $^{1)}$, Pebri Hastuti' ${ }^{2}$, Dedi Irawan ${ }^{3)}$ \\ 123) Program Studi Pendidikan Ekonomi, Fakultas Ekonomi, Universitas Negeri Medan \\ E-mail: dras_ruslan@yahoo.com ${ }^{1)}$, pebrihastuti06@gmail.com ${ }^{2)}$, simdigdedyirawan@ gmail.com ${ }^{3)}$
}

\begin{abstract}
This research is titled foreign investment (PMA) and domestic investment (PMDN) on gross regional domestic product (GRDP) in North Sumatra. The purpose of this study was to analyze the effect of PMA and PMDN on GRDP. The method used in this research is a quantitative method that uses mathematical models to present facts or describe statistics to show the relationship between variables namely capital development and domestic investment of regional domestic products in North Sumatra. The results of data processing showed that PMA and PMDN variables in districts / cities in North Sumatra did not have a positive and significant effect on GRDP variables. Meanwhile, procedurally, PMA variable does not have a significant effect on GRDP while PMDN has a positive and significant effect on GRDP.
\end{abstract}

Kata Kunci : Foreign Capital, Domestic Capital, Transition 


\section{PENDAHULUAN}

Pembangunan daerah merupakan bagian integral dan sebagai penjabaran dari pembangunan nasional dalam rangka pencapaian sarana pembangunan yang disesuaikan dengan potensi, aspirasi, dan permasalahan pembangunan daerah. Pembangunan daerah juga diharapkan dapat memotivasi peningkatan kreatifitas dan inisiatif untuk dapat lebih menggali dan mengembangkan potensipotensi yang dimiliki oleh tiap-tiap daerah, dan dilaksanakan secara terpadu, serasi, terarah, agar pembangunan di tiap daerah dapat benar-benar sesuai dengan prioritas dan potensi daerahnya (Nugroho, 2002)

Secara umum peranan pengeluaran pemerintah daerah yang dibiayai APBD khususnya pengeluaran untuk human capital dan infrastruktur fisik, dapat mempercepat pertumbuhan, tetapi pada sisi lain pembiayaan dari pengeluaran pemerintah tersebut dapat memperlambat pertumbuhan ekonomi. Hal ini sangat tergantung pada sejauh mana produktifitas pengeluaran pemerintah tersebut dan distorsi pajak yang ditimbulkannya, yang mana dalam konteks ini pemerintah baik secara langsung maupun tidak langsung dapat mempengaruhi total output (PDRB). Dengan meningkatnya investasi yang dapat meningkatkan kapasitas produksi yang diharapkan dapat meningkatkan produktivitas untuk menghasilkan output dan nilai tambah, sehingga akan meningkatkan pertumbuhan ekonomi. Peningkatan kapasitas produksi tersebut dapat diperoleh melalui investasi swasta (Private Investment) yang bisa disebut dengn penanaman modal dalam negeri (PMDN) maupun investasi luar negeri yang disebut dengan Penanaman Modal Asing (PMA).

Lagkah awal dalam kegiatan pembangunan adalah penanaman modal. Pentingnya pembentukan modal menjadi bahan perhatian terutama dalam investasi swasta. Hal ini senada dengan pendapat (Zaris: 1987) yang menyatakan bahwa investasi swasta berperan pentingan dalam pembentukan pola pembangunan di daerah, sehingga melalui investasi ini terbentuknya modal daerah (regional capital information). Hal ini merupakan konsekuensi logis dari terbatasnya sumber daya, teknologi, dan modal yang dimiliki oleh daerah. Berdasarkan data statistik menyatakan bahwa realisasi jumlah proyek sepanjang 2017 adalah sebanyak 187 meningkat dari tahun sebelumnya 145. Peningkatan jumlah realisasi proyek pada tahun 2017 tentunya berdampak terhadap pertumbuhan ekonomi di Sumatera Utara yang pada tahun 2016 hanya berkisar di 4,50\% meningkat menjadi 5,09\%.

Berdasarkan kajian data Badan Pusat Statistik (BPS) tersebut maka penulis tertarik untuk mengkaji secara teoritis dan statistik bagaimana pengaruh PMDN dan PMA terhadap peningkatan PDRB di provinsi Sumatera Utara.

\section{TINJAUAN PUSTAKA}

Pertumbuhan ekonomi (economic growth) secara paling sederhana dapat diartikan sebagai pertambahan output atau pertambahan pendapatan nasional agregat dalam kurun waktu tertentu, misalkan satu tahun. Perekonomian suatu negara dikatakan mengalami pertumbuhan jika balas jasa riil terhadap penggunaan faktor - faktor produksi pada tahun tertentu lebih besar daripada tahun - tahun sebelumnya. Dengan demikian, pengertian pertumbuhan ekonomi dapat diartikan sebagai kenaikan kapasitas produksi barang dan jasa secara fisik dalam kurun waktu tertentu (Prasetyo, 2009). Pertumbuhan ekonomi adalah proses kanaikan output perkapita dalam jangka panjang, dimana penekanannya pada tiga hal yaitu proses, output perkapita dan jangka panjang. Pertumbuhan ekonomi merupakan suatu "proses", bukan merupakan gambaran ekonomi pada suatu saat. Disini dilihat aspek dinamis dari suatu perekonomian, yaitu melihat bagaimana suatu perekonomian berkembang atau berubah dari waktu ke waktu. Pertumbuhan ekonomi juga berkaitan dengan kenaikan "output perkapita". Dalam pengertian ini ada dua sisi yang perlu diperhatikan yaitu output total dan jumlah penduduk, sebab hanya apabila kedua aspek tersebut dijelaskan, makaperkembangan output perkapita bisa dijelaskan.

Kemudian aspek yang ketiga adalah pertumbuhan ekonomi perspektif waktu jangka panjang, yaitu apabila selama jangka waktu yang cukup panjang tersebut output perkapita menunjukkan kecenderungan yang jelas untuk menaik (Boediono, 2009). Berdasarkan dua pengertian pertumbuhan ekonomi di atas dapat 
disimpulkan bahwa pertumbuhan ekonomi dapat terjadi jika suatu negara atau suatu daerah mampu menyediakan barang ekonomi bagi penduduknya, akibat dari hasil penggunaan faktor-faktor produksi yang digunakan dalam jangka panjang dan pada akhirnya akan diikuti dengan peningkatan pendapatan perkapita. Menurut teori pertumbuhan ekonomi Neo Klasik ada tiga faktor atau komponen utama dalam pertumbuhan ekonomi dari setiap bangsa. Ketiga faktor tersebut adalah: (Todaro, 2003) Akumulasi modal, yang meliputi semua bentuk atau jenis investasi baru yang ditanamkan pada tanah, peralatan fisik, dan modal atau sumber daya manusia. Pertumbuhan penduduk, yang pada akhirnya akan memperbanyak jumlah angkatan kerja. Kemajuan teknologi. Model pertumbuhan Solow sebenarnya digunakan untuk menjelaskan bagaimana pertumbuhan persediaan modal, pertumbuhan angkatan kerja, dan kemajuan teknologi berinteraksi dalam perekonomian, serta bagaimana pengaruhnya terhadap output barang dan jasa suatu negara secara keseluruhan.

\section{Produk Domestik Regional Bruto}

Salah satu indikator penting untuk mengetahui kondisi ekonomi di suatu daerah dalam suatu periode tertentu ditunjukkan oleh data Produk Domestik Regional Bruto (PDRB), baik atas dasar harga yang berlaku atau atas dasar harga konstan. PDRB didefinisikan sebagai jumlah nilai tambah yang dihasilkan oleh seluruh unit usaha dalam satu daerah tertentu, atau merupakan jumlah seluruh nilai barang dan jasa akhir yang dihasilkan oleh seluruh unit ekonomi di suatu daerah. PDRB atas dasar harga berlaku menggambarkan nilai tambah barang dan jasa yang dihitung menggunakan harga yang berlaku pada setiap tahun, sedangkan PDRB atas harga konstan menunjukan nilai tambah barang dan jasa tersebut yang dihitung menggunakan harga yang berlaku pada satu waktu tertentu sebagai harga dasar (Widodo, 2006). PDRB merupakan penjumlahan dari semua barang dan jasa akhir atau semua nilai tambah yang dihasilkan oleh suatu daerah dalam periode waktu tertentu (1 tahun). Untuk menghitung nilai seluruh produksi yang dihasilkan suatu perekonomian dalam suatu tahun tertentu dapat digunakan 3 cara penghitungan, yaitu : (Widodo, 2006)
1. Cara Produksi.

Dengan cara ini pendapatan nasional dihitung dengan menjumlahkan nilai produksi barang atau jasa yang diwujudkan oleh berbagai sektor lapangan usaha pada suatu wilayah dalam jangka waktu tertentu (satu tahun).

2. Cara Pengeluaran.

Menurut cara ini pendapatan nasional adalah jumlah nilai pengeluaran konsumsi rumah tangga, konsumsi pemerintah, pembentukan modal tetap domestik bruto, perubahan stok, dan ekspor neto (ekspor dikurangi impor).

3. Cara Pendapatan.

Dalam penghitungan ini pendapatan nasional diperoleh dengan cara menjumlahkan pendapatan yang diterima oleh faktor-faktor produksi yang digunakan untuk mewujudkan pendapatan nasional. Data pendapatan regional adalah salah satu indikator makro yang dapat nunjukan kondisi perekonomian regional setiap tahun. Manfaat yang didapat atau diperoleh adalah :

a. PDRB atas dasar harga berlaku/nominal

Mengetahui kemampuan sumberdaya ekonomi yang dihasilkan oleh suatu wilayah/ provinsi. Nilai PDRB yang besar menunjukan kemampuan sumberdaya ekonomi yang besar pula. Mengetahui pendapatan yang memungkinkan dapat dinikmati oleh penduduk suatu wilayah/provinsi.

b. PDRB atas dasar harga konstan

Mengetahui laju pertumbuhan ekonomi secara keseluruhan/ setiap sektor ekonomi dari tahun ke tahun. Mengetahui laju pertumbuhan konsumsi, investasi, dan perdagangan luar negeri, perdagangan antar pulau/ antar provinsi. Setelah melihat pada uraian PDRB di atas dapat diambil kesimpulan bahwa PDRB merupakan nilai secara keseluruhan dari barang dan jasa yang dihasilkanoleh masyarakat/ warga dalam suatu wilayah atau daerah dalam waktu tertentu (1 tahun). PDRB juga merupakan ukuran laju pertumbuhan suatu daerah. PDRB dalam hal ini juga dapat berarti jumlah nilai tambah yang timbul dari semua unit produksi 
di dalam suatu wilayah dalam jangka waktu tertentu.

\section{Penanaman Modal Dalam Negeri (PMDN)}

Dalam Undang-Undang no 6 tahun 1968 dan Undang-Undang nomor 12 tahun 1970 tentang Penanaman Modal Dalam Negeri (PMDN), disebutkan terlebih dulu definisi modal dalam negeri pada pasal 1 , yaitu sebagai berikut : a. Undang-undang ini menjelaskan bahwa "modal dalam negeri" adalah : bagian dari kekayaan masyarakat Indonesia termasuk hak-hak dan benda-benda, baik yang dimiliki Negara maupun swasta asing yang berdomosili di Indonesia yang disisihkan atau disediakan guna menjalankan suatu usaha sepanjang modal tersebut tidak diatur oleh ketentuanketentuan pasal 2 UU No. 12 tahun 1970 tentang penanaman modal asing. Pihak swasta yang memiliki modal dalam negeri tersebut dalam ayat 1 pasal ini dapat terdiri atas perorangan dan/ atau badan hukum yang didirikan berdasarkan hukum yang berlaku di Indonesia. Kemudian dalam Pasal 2 disebutkan bahwa, Yang dimaksud dalam Undang-Undang ini dengan "Penanaman Modal Dalam Negeri" ialah penggunaan daripada kekayaan seperti tersebut dalam pasal 1 , baik secara langsung atau tidak langsung untuk menjalankan usaha menurut atau berdasarkan ketentuan Undang-undang ini.

Menurut UU no. 1 Th. 1967 dan UU no 11 Th. 1970 tentang PMA, yang dimaksud dengan Penanaman Modal Asing (PMA) adalah penanaman modal asing secara langsung yang dilakukan menurut atau berdasarkan ketentuan Undang-undang ini dan yang digunakan untuk menjalankan Perusahaan di Indonesia, dalam arti bahwa pemilik modal secara langsung menanggung resiko dari penanaman modal tersebut. Sedangkan pengertian Modal Asing antara lain

a. Alat pembayaran luar negeri yang tidak merupakan bagian kekayaan devisa Indonesia, yang dengan persetujuan pemerintah digunakan untuk pembiayaan perusahaan di Indonesia.

b. Alat untuk perusahaan, termasuk penemuan baru milik orang asing dan bahan- bahan yang dimasukan dari luar negeri ke dalam wilayah Indonesia selama alat-alat tersebut tidak dibiayai dari kekayaan Indonesia. Bagian dari
NIAGAWAN Vol 9 No 1 Maret 2020

hasil perusahaan yang berdasarkan undang-undang ini diperkenankan ditransfer, tetapi dipergunakan untuk membiayai perusahaan di Indonesia.

\section{METODE PENELITIAN}

\section{Jenis dan Sumber Data}

Penelitian ini menggunakan data sekunder yang dicatat secara sistematis dan berbentuk data runtut waktu (time series). Data diperoleh dari laporan Badan Pusat Statistik (BPS) Sumatera Utara khususnya data tahun 2001 sampai dengan tahun 2017. Data yang diteliti meliputi data Produk Domestik Regional Bruto, Penanaman Modal Dalam Negeri, dan Penanaman Modal Asing.

\section{Metode Pengumpulan Data}

Dalam penelitian ini menggunakan metode dokumentasi yang bersumber dari Badan Pusat Statistik (BPS) dengan mengambil seluruh populasi yaitu sebanyak 33 kabupaten/kota di Provinsi Sumatera Utara maupun melakukan telaah terhadap berbagai literatur seperti buku, jurnal, media cetak serta laporan-laporan ilmiah yang berhubungan dengan objek penelitian.

\section{Teknik Analisis Data}

Penelitian ini menggunakan metode penelitian kuantitatif dengan menggunakan data time series. Teknik analisis data yang digunakan dalam menganalisis variabel variabel yang berpengaruh terhadap PDRB (Produk Domestik Regional Bruto) di Provinsi Sumatera Utara menggunakan teknik analisis regresi linear berganda dengan program SPSS 24.

\section{Identifikasi Variabel}

Pada dasarnya ada dua jenis variabel yang penulis pergunakan dalam penelitian ini yaitu sebagai berikut:

a. Variabel terikat, merupakan variabel yang nilainya dipengaruhi oleh variasi yang dialami oleh variabel bebas. Pada penelitian ini yang menjadi variabel terikatnya adalah PDRB Sumatera Utara.

b. Variabel bebas, merupakan variabel yang akan mempengaruhi nilai variabel terikat dari variasi atau perubahan yang dialami variabel bebas. Dalam penelitian ini yang menjadi variabel bebasnya adalah PMDN dan PMA. 


\section{Definisi Operasional Variabel}

Pengertian dan batasan variabel yang digunakan dalam penelitian ini adalah sebagai berikut:

\section{a. $\mathrm{PMDN}(\mathrm{X} 1)$}

PMDN (Penanaman Modal Dalam Negeri) yang dimaksud dalam penelitian ini adalah keseluruhan nilai realisasi investasi kegiatan penanaman modal untuk melakukan usaha di wilayah Negara Republik Indonesia yang dilakukan oleh penanam modal dalam negeri dengan menggunakan modal dalam negeri yang dilakukan berdasarkan ketentuan ketentuan Undang - undang di Provinsi Sumatera Utara dalam kurun waktu 20012017.

b. PMA (X2)

PMA (Penanaman Modal Asing) yang dimaksud dalam penelitian ini adalah keseluruhan nilai realisasi investasi asing yang memperoleh fasilitas dari pemerintah yang dilakukan berdasarkan ketentuan Undang-undang di Provinsi Sumatera Utara dalam kurun waktu 2001- 2017.

\section{c. $\operatorname{PDRB}(\mathrm{Y})$}

PDRB adalah total PDRB (Y) di Provinsi Sumatera Utara dari tahun ke tahun dalam rupiah (Rp).

\section{HASIL DAN PEMBAHASAN}

Pada bab ini akan menelaah kebenaran dari hipotesis penelitian dan akan membahas

\section{NIAGAWAN Vol 9 No 1 Maret 2020}

tentang Pengaruh PMA, PMDN, Pengaruh PMA, PMDN. Dalam model penelitian ini maka digunakan analisis regresi linear berganda untuk menjawab hipotesis penelitian. Proses analisis dilakukan dengan menggunakan program SPSS.

Suatu model yang baik harus memenuhi kriteria BLUE (Best Linear Suatu model yang baik harus memenuhi kriteria BLUE (Best Linear Unbiased Estimator) yaitu memnuhi asumsi klasik (Gujarati, 1995). Dalam regresi terdapat beberapa asumsi dasar yang menghasilkan estimator linier tidak bias. Dengan memnuhi beberapa asumsi tersebut, maka hasil yang diperoleh dapat lebih akurat dan mendekati kenyataan. Asumsi-asumsi dasar tersebut dikenal dengan asumsi klasik.

\section{Uji Asumsi Klasik}

Uji asumsi klasik digunakan sebagai syarat dalam menggunakan model regresi agar hasil regresi yang diperoleh merupakan estimasi yang tepat.

\section{Uji Normalitas}

Uji normalitas berguna untuk menguji apakah dalam model regresi, variabel dependen dan variabel independen memiliki distribusi normal atau tidak. Uji normalitas pada penelitian ini menggunakan distribusi pada grafik $P$-P plot. Berikut ini hasil uji normalitas menggunakan grafik $P-P$ Plot menggunakan bantuan aplikasi SPSS versi 20:

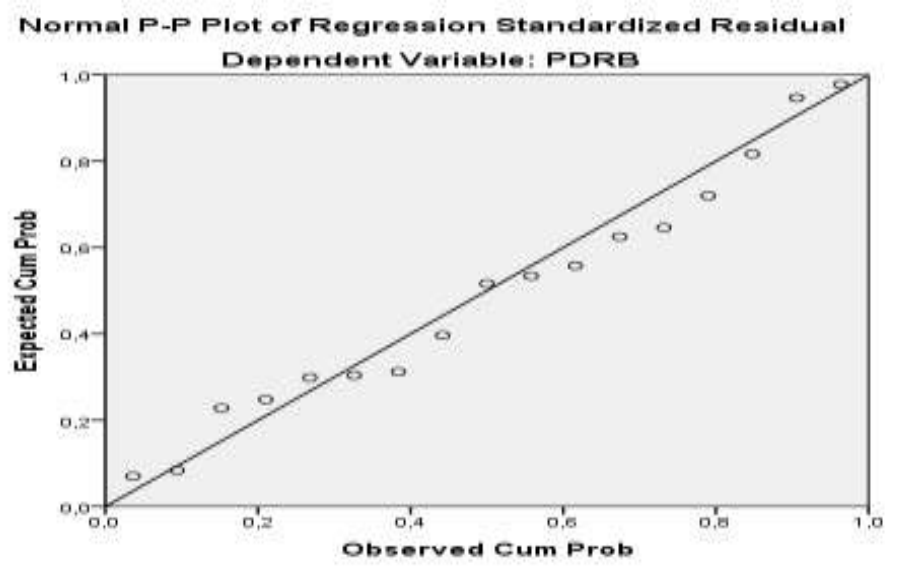

Berdasarkan gambar 1 di atas, dapat dilihat bahwa data menyebar disekitar garis diagonal dan mengikuti arah garis diagonal pada grafik histogram, hal ini menunjukkan bahwa pola distribusi normal. Jadi dapat disimpulkan bahwa berdasarkan grafik $P-P$ plot, model regresi memenuhi asumsi

\section{Uji Multikolinieritas}

Uji Multikolinieritas berguna untuk menguji apakah model regresi ditemukan adanya korelasi antar variabel independen. Cara mengetahui ada tidaknya penyimpangan uji multikolinieritas adalah dengan melihat nilai Tolerance dan VIF masing-masing variabel 
Tabel 6. Coefficients ${ }^{a}$

\begin{tabular}{|c|c|c|c|c|c|c|c|}
\hline \multirow[t]{2}{*}{ Model } & \multicolumn{2}{|c|}{$\begin{array}{c}\text { Unstandardized } \\
\text { Coefficients }\end{array}$} & \multirow{2}{*}{$\begin{array}{c}\text { Standardized } \\
\text { Coefficients }\end{array}$} & \multirow[t]{2}{*}{$\mathrm{t}$} & \multirow[t]{2}{*}{ Sig. } & \multicolumn{2}{|c|}{$\begin{array}{l}\text { Collinearity } \\
\text { Statistics }\end{array}$} \\
\hline & B & Std. Error & & & & Tolerance & VIF \\
\hline (Constant) & 104683,737 & 26440,792 & & 3,959 & ,001 & & \\
\hline $1 \mathrm{PMDN}$ & ,023 & ,012 & ,323 & 1,827 & ,089 & ,256 & 3,903 \\
\hline PMA & ,278 &, 076 &, 650 & 3,679 & ,002 & ,256 & 3,903 \\
\hline
\end{tabular}

a. Dependent Variable: PDRB

Melihat hasil pada tabel 2, hasil perhitungan nilai variabel independen memiliki nilai Tolerance lebih dari 0.10 dengan nilai Tolerance masing-masing variabel independen bernilai 0,256. Sementara itu hasil perhitungan nilai Variance Inflation Factor (VIF) juga menunjukkan VIF dari variabel independen yang memiliki nilai kurang dari 10 dengan nilai 3,903. Merujuk hasil perhitungan nilai Tolerance dan VIF dapat disimpulkan bahwa terdapat multikolinieritas antar variabel independen dalam model regresi. Penyebab nya antara lain Kesalahan teoritis dalam pembentukan model fungsi regresi yang dipergunakan/ memasukkan variabel bebas yang hampir sama, bahkan sama atau Terlampau kecilnya jumlah pengamatan yang akan dianalisis dengan model regresi.

\section{Uji Heteroskedastisitas}

Uji heteroskedastisitas bertujuan untuk menguji dalam model regresi terjadi ketidaksamaan varians dari residual satu pengamatan ke pengamatan yang lain. Cara untuk mengetahui terjadi heteroskedastisitas atau tidak yaitu dengan melihat Grafik Plot antara nilai prediksi variabel dependen yaitu ZPRED dengan residualnya SRESID. Tidak terjadi heteroskedastisitas yaitu apabila tidak ada pola yang jelas, serta titik-titik menyebar di atas dan di bawah angka 0 pada sumbu Y.

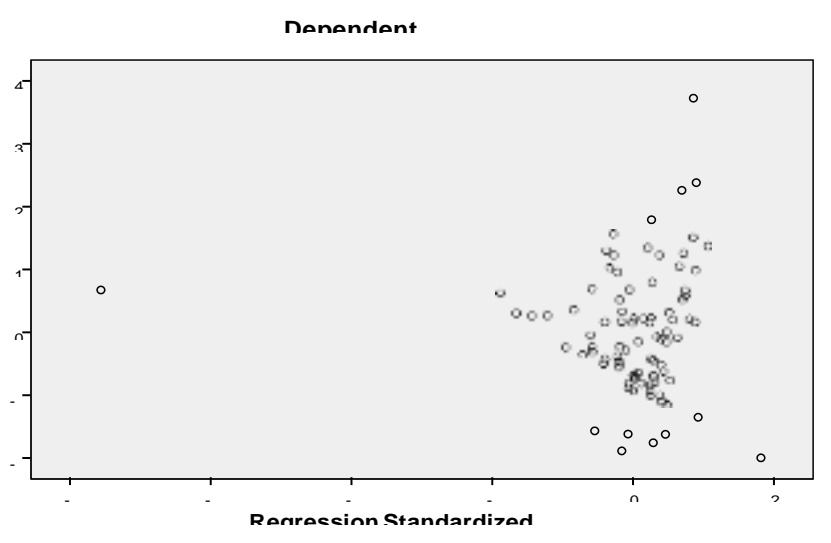

Gambar 2. Grafik scatterplot

Berdasarkan gambar 2 di atas terlihat bahwa tidak ada pola yang jelas serta titik-titik tersebut menyebar di atas dan di bawah angka 0 pada sumbu Y. Hal ini menunjukkan bahwa data dalam penelitian ini tidak terjadi heteroskedastisitas.

\section{Uji Autokorelasi}

Uji autokorelasi bertujuan untuk menguji dalam model regresi linear ada atau tidak korelasi antara kesalahan pengganggu pada periode $\mathrm{t}$ dengan kesalahan pengganggu pada periode t-1 atau periode sebelumnya. Uji autokorelasi pada penelitian ini menggunakan uji Durbin Watson. Berikut hasil uji autokorelasi: 
Tabel 7. Model Summary

\begin{tabular}{|c|c|c|c|c|c|}
\hline Model & $\mathbf{R}$ & R square & $\begin{array}{l}\text { Adjusted R } \\
\text { Aquare }\end{array}$ & $\begin{array}{l}\text { Std. Error of the } \\
\text { estimate }\end{array}$ & Durbin-Watson \\
\hline \multirow[t]{2}{*}{1} & & & & & \\
\hline &, $942^{\mathrm{a}}$ & ,888 & ,872 & 72510,98071 & 2,103 \\
\hline
\end{tabular}

a. Predictors: (Constant), PMA, PMDN

b. Dependent Wariabl: PDRB

Berdasarkan tabel 7 di atas nilai Durbin Watson sebesar 2.103, pembanding menggunakan nilai signifikansi $5 \%$, jumlah sampel 17 (n), dan jumlah variable independen $3(\mathrm{k}=3)$, maka di tabel DurbinWatson akan didapat nilai du sebesar 1,7101. Karena nilai DW 2,103 lebih besar dari batas atas (du) 1,71 dan kurang dari 4 - 1.73 (2.29), maka dapat disimpulkan bahwa tidak terdapat autokorelasi.
Adapun hasil analisis analisis regresi dapat dijabarkan sebagai berikut: pertama, Model Pertama Regresi Linear Berganda Hasil penelitian mengguanakan model regresi regresi linear berganda yang diterapkan untuk menguji masing-masing pengaruh variabel independen terhadap variabel dependen. Berdasarkan analisis diperoleh hasil sebagai berikut:

Tabel 1. Coefficients ${ }^{\mathrm{a}}$

\begin{tabular}{|c|c|c|c|c|c|c|c|}
\hline \multirow[t]{2}{*}{ Model } & \multicolumn{2}{|c|}{$\begin{array}{l}\text { Unstandardized } \\
\text { Coefficients }\end{array}$} & $\begin{array}{c}\text { Standardized } \\
\text { Coefficients }\end{array}$ & \multirow[t]{2}{*}{$\mathrm{t}$} & \multirow[t]{2}{*}{ Sig. } & \multicolumn{2}{|c|}{$\begin{array}{l}\text { Collinearity } \\
\text { Statistics }\end{array}$} \\
\hline & B & Std. Error & Beta & & & Tolerance & VIF \\
\hline (Constant) & 104683,737 & 26440,792 & & 3,959 &, 001 & & \\
\hline 1 PMDN & 023 & ,012 & ,32 & 1,827 & ,089 & ,256 & 3,903 \\
\hline PMA & 278 & 076 & 65 & 3,679 &, 002 & ,256 & 3,903 \\
\hline
\end{tabular}

a. Dependent Variable: PDRB

Berdasarkan tabel di atas maka dapat diambil persamaan regresi sebagai berikut: Y $=104683,737 \times 10^{6}+0,023 \mathrm{X}_{1}+0,278 \mathrm{X}_{2}$. Berdasarkan persamaan tersebut, maka dapat diketahui bahwa: 1) nilai konstanta = 104683,737 x $10^{6}$ artinya jika tidak dipengaruhi oleh PMD, PMA maka PDRB Kota Medan bernilai negatif; 2) Nilai Koefisien PMDN (X1) sebesar 0,023 artinya jika PMA bertambah satu-satuan, maka akan terjadi peningkatan PDRB Kota Medan sebesar Rp 0,278 dengan Asumsi X2 Konstan; 3) Nilai Koefisien PMA (X2) adalah sebesar 0,278 berarti jika PMDN meningkat satu satuan, maka akan terjadi peningkatan PDRB Kota Medan sebesar Rp 0,278 dengan asumsi X1 dan X2 Konstan. Adapun berdasarkan model Summary dapat diperoleh hasil, sebagai berikut:

Tabel 2. Model Summary ${ }^{b}$

\begin{tabular}{|l|r|r|r|r|c|}
\hline Model & \multicolumn{1}{|c|}{$\mathrm{R}$} & R Square & $\begin{array}{c}\text { Adjusted R } \\
\text { Square }\end{array}$ & $\begin{array}{l}\text { Std. Error of } \\
\text { the Estimate }\end{array}$ & $\begin{array}{c}\text { Durbin- } \\
\text { Watson }\end{array}$ \\
\hline 1 &, $942^{\mathrm{a}}$ &, 888 &, 872 & 72510,98071 & 2,103 \\
\hline
\end{tabular}

a. Predictors: (Constant), PMA, PMDN

b. Dependent Variable: PDRB

Berdasarkan hasil perhitungan sebagaimana tersaji pada Tabel 2 di atas, maka koefisien determinasi atau nilai (pada lampiran Regreesion) menunjukkan nilai 0,888 atau $88,8 \%$. Hal tersebut bisa diartikan bahwa 88,8\% nilai PDRB dapat diproksi dengan menggunakan PMDN, PMA, sedangkan sisanya sebesar $12,2 \%$ dijelaskan oleh variabel-variabel lain diluar variabel PMA, PMDN. Nilai $\mathrm{R}^{2}$ dalam penelitian ini 
relatif tinggi, sehingga bisa dikatakan bahwa variabel PDN, PMA berpotensi memberikan pengaruh yang besar terhadap nilai PDRB Kota Medan.

Untuk menguji hipotesis pertama yaitu apakah variabel bebas (independent) secara bersama-sama memberikan penagruh atau tidak terhadap variabel tidak bebas (dependent) dapat dilihat dari hasil uji $\mathrm{F}$, sedangkan untuk menguji hipotesis kedua yaitu apakah secara parsial variabel bebas berpengaruh nyata terhadap variabel tidak bebas maka digunakan uji t.
NIAGAWAN Vol 9 No 1 Maret 2020

Uji $\mathrm{t}$ dilakukan untuk mengetahui apakah ada pengaruh secara parsial variabel bebas terhadap variabel terikat. Adapun kriteria yang digunakan untuk melihat pengaruh secara parsial dari variabel terikat dengan variabel terikat dengan cara melihat nilai p-value (probabilitas) pada Tabel Coefficients.

Dari hasil perhitungan dengan SPSS versi 20 terlihat bahwa nilai $\mathrm{t}$ adalah sebagai berikut:

Tabel 3. Hasil Perhitungan $t_{\text {hitung }}$ untuk Pengaruh PMDN terhadap PDRB Kota Medan

\begin{tabular}{|c|c|c|c|}
\hline Variabel & $\mathbf{t}_{\text {hitung }}$ & $\mathbf{p}_{\text {value }}$ & keterangan \\
\hline PMDN & 1,827 & 0,089 & Tidak Signifikan \\
\hline
\end{tabular}

Berdasarkan Tabel 3 dapat diartikan bahwa tidak terdapat pengaruh signifikansi variabel PMDN terhadap PDRB. Hal tersebut terlihat dari nilai probabilitas $(0,089)$ memiliki nilai lebih besar dari nilai alpha 5\%. Sehingga hasil perhitungan menunjukkan bahwa PMDN tidak berpengaruh secara positif dan signifikan terhadap nilai PDRB Kota Medan.

Tabel 4. Hasil Perhitungan $t_{\text {hitung }}$ untuk Pengaruh PMDN terhadap PDRB Kota Medan

erda

\begin{tabular}{||c|c|c|c|}
\hline \multicolumn{1}{c||}{ Variabel } & $\mathbf{t}_{\text {hitung }}$ & $\mathbf{p}_{\text {value }}$ & Keterangan \\
\hline BMA & 3,679 & 0,002 & Tidak Signifikan \\
\hline
\end{tabular}

dari nilai sarkan Tabel 4 dapat diartikan bahwa tidak terdapat pengaruh signifikan variabel PMA terhadap PDRB. Hal tersebut terlihat dari nilai probabilitas $(0,002)$ memiliki nilai lebih besar alpha 5\%. Sehingga hasil perhitungan menunjukkan bahwa PMA tidak berpengaruh secara positif dan signifikan terhadap nilai PDRB Kota Medan.

Tabel 5. Hasil Perhitungan ANOVA

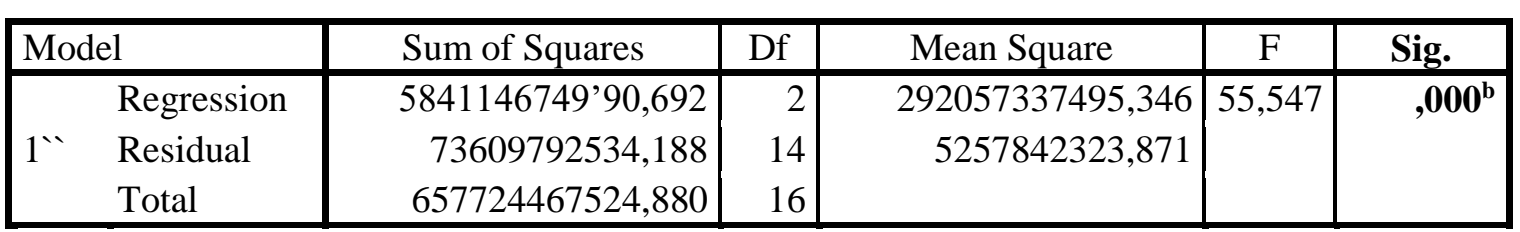

a. Dependent Variable: PDRB

b. Predictors: (Constant), PMA, PMDN

Berdasarkan Tabel 5, terlihat bahwa hasil uji $\mathrm{F}$ pada perhitungan data penelitian menggunakan program SPSS versi 20.0. Nilai $F$ hitung pada hasil perhitungan adalah sebesar 55,547 dengan nilai probabilitas (p-value) sebesar 0,000. Nilai $\mathrm{p}$ value selanjutnya dikonsultasikan dengan nilai alpha.

Berdasarkan perhitungan langkah di atas, menunjukkan bahwa model penelitian yang digunakan sudah tepat. Dengan kata lain, terdapat pengaruh yang simultan dari variabel PMDN, PMA terhadap nilai PDRB Kota Medan. 
Tabel 8. ANOVA ${ }^{\mathrm{a}}$

\begin{tabular}{|rl|r|r|r|r|c|}
\hline \multicolumn{1}{|c|}{ Model } & \multicolumn{1}{|c|}{ Sum of Squares } & \multicolumn{1}{c|}{ Df } & \multicolumn{1}{c|}{ Mean Square } & F & Sig. \\
\hline \multirow{4}{*}{$1^{\prime \prime}$} & Regression & 584114674990,692 & 2 & 292057337495,346 & 55,547 & $\mathbf{, 0 0 0}^{\mathbf{b}}$ \\
& Residual & 73609792534,188 & 14 & 5257842323,871 & & \\
& Total & 657724467524,880 & 16 & & & \\
\hline
\end{tabular}

a. Dependent Variable: PDRB

b. Predictors: (Constant), PMA, PMDN

Berdasarkan hasil perhitungan dengan menggunakan program SPSS 20 pada Tabel 8, diperoleh nilai signifikansi sebesar 0,000 dan level signifikan pada 0,05 . Hal ini variabel PMDN dan PMA terhadap variabel PDRB secara bersama-sama (simultan) berpengaruh satu sama lain. Sehingga dapat disimpulkan bahwa variabel Penanaman Modal Dalam Negeri (PMDN) dan Variabel Penanaman
Modal Asing (PMA) secara bersama-sama berpengaruh signifikan terhadap Produk Domestik Regional Bruto (PDRB) di Kota Medan. Pernyataan ini sesuai dengan pendapat Penanaman Modal Dalam Negeri dan Penanaman Modal Asing berpengaruh signifikan secara simultan terhadap Produk Domestik (Unud, 2012)

\section{Uji Parsial t}

Tabel 9 Coefficients ${ }^{a}$

\begin{tabular}{|c|c|c|c|c|c|c|c|}
\hline & & & $\begin{array}{c}\text { Standardized } \\
\text { Coefficients }\end{array}$ & \multirow[t]{2}{*}{$\mathbf{t}$} & \multirow[t]{2}{*}{ Sig. } & \multicolumn{2}{|c|}{$\begin{array}{l}\text { Collinearity } \\
\text { Statistics }\end{array}$} \\
\hline & B & Std. Error & Beta & & & Tolerance & VIF \\
\hline (Constant) & 104683,737 & 26440,792 & & 3,959 & ,001 & & \\
\hline $1 \mathrm{PMDN}$ & ,023 & ,012 & ,323 & 1,827 & ,089 & ,256 & 3,903 \\
\hline PMA & ,278 & ,076 & ,650 & 3,679 &, 002 & ,256 & 3,903 \\
\hline
\end{tabular}

a. Dependent Variable: PDRB

Berdasarkan hasil perhitungan dengan menggunakan program SPSS 20 seperti terlihat pada Tabel 9, variabel PMDN memiliki t hitung sebesar 1,827 dan nilai signifikan sebesar 0,089. Ketentuan pengambilan keputusan hipotesis diterima atau ditolak didasarkan pada besarnya nilai signifikansi. Jika signifikansi lebih kecil atau sama dengan $0,05(\leq 0,05)$ maka hipotesis diterima.

Hasil penelitian diperoleh nilai signifikansi sebesar 0,089>0,05, maka dapat diartikan bahwa hipotesis (X1) ditolak atau tidak memiliki pengaruh yang signifikan. Maka dengan ini disimpulkan bahwa adanya Penanaman Modal Dalam Negeri (PMDN) tidak berpengaruh secara signifikan terhadap peningkatan Produk Domestik Regional Bruto (PDRB). Hal ini dapat terjadi disebabkan oleh karena jumlah Penanaman Modal Dalam
Negeri (PMDN) dalam jumlah yang sedikit dibandingkan dengan jumlah Penanaman Modal Asing (PMA) sehingga tidak berpengaruh signifikan terhadap peningkatan jumlah Produk Domestik Bruto (PDRB).

Berdasarkan hasil perhitungan dengan menggunakan program SPSS 20 seperti terlihat pada di atas, variabel PMA memiliki $\mathrm{t}$ hitung sebesar 3,679 dan nilai signifikan sebesar 0,002 Ketentuan pengambilan keputusan hipotesis diterima atau ditolak didasarkan pada besarnya nilai signifikansi. Jika signifikansi lebih kecil atau sama dengan $0,05(\leq 0,05)$ maka hipotesis diterima. Hasil penelitian diperoleh nilai signifikansi sebesar $0,002<0,05$, maka dapat diartikan bahwa hipotesis ini diterima atau memiliki pengaruh yang signifikan. Maka dengan ini disimpulkan bahwa adanya Penanaman Modal Asing (PMA) berpengaruh secara signifikan terhadap 
p-ISSN : 2301-7775

e-ISSN : 2579-8014

NIAGAWAN Vol 9 No 1 Maret 2020

peningkatan Produk Domestik Regional Bruto menyatakan bahwa semakin naik PMA maka (PDRB). Hal ini senada dengan pendapat yang semakin meningkat PDRB (Studi et al., 2015).

\section{Koefisien Determinasi}

Model Summary ${ }^{b}$

\begin{tabular}{|l|r|r|r|r|c|}
\hline Model & \multicolumn{1}{|c|}{$\mathrm{R}$} & $\mathrm{R}$ Square & $\begin{array}{c}\text { Adjusted R } \\
\text { Square }\end{array}$ & $\begin{array}{c}\text { Std. Error of } \\
\text { the Estimate }\end{array}$ & $\begin{array}{c}\text { Durbin- } \\
\text { Watson }\end{array}$ \\
\hline 1 &, $942^{\mathrm{a}}$ &, 888 &, 872 & 72510,98071 & 2,103 \\
\hline
\end{tabular}

a. Predictors: (Constant), PMA, PMDN

b. Dependent Variable: PDRB 
Koefisien determinasi (R2) pada intinya mengukur seberapa besar kemampuan model dalam menerangkan variasi variabel dependen. Berdasarkan dari uji regresi linier berganda terhadap model penelitian dengan menggunakan variabel debt to equity ratio diperoleh nilai adjusted R2 sebesar 0,872 atau sebesar 8,7\%. Sedangkan R2 nya sebesar 0,88 atau $88 \%$. Dengan demikan maka dapat disimpulkan bahwa $88 \%$ variabel- variabel PMDN dan PMA mampu di jelaskan oleh variabel PDRB, sedangkan sisanya yaitu $12 \%$ dijelaskan oleh variabel-variabel lain di luar model.

\section{KESIMPULAN DAN SARAN}

Pada Uji normalitas data menyebar disekitar garis diagonal dan mengikuti arah garis diagonal pada grafik histogram berdasarkan grafik $P-P$ plot, model regresi memenuhi asumsi normalitas. Pada Uji Multikolinieritas terdapat multikolinieritas antar variabel independen dalam model regresi. Penyebab nya antara lain Kesalahan teoritis dalam pembentukan model fungsi regresi yang dipergunakan/ memasukkan variabel bebas yang hampir sama, bahkan sama atau Terlampau kecilnya jumlah pengamatan yang akan dianalisis dengan model regresi. Dalam penelitian ini tidak terjadi heteroskedastisitas dan tidak terdapatautokorelasi pada uji heteroskedastisitas dan uji autokorelasi

\section{REFERENSI}

Boediono. 2009. Teori Pertumbuhan Ekonomi. Yogyakarta: BPFE UGM.

Handitya Surya Nugraha.2014. Penanaman Modal Dalam Negeri, dan Belanja daerah Terhadap Produk Domestik Regional Bruto (pdrb) Provinsi Jawa Tengah [Skripsi]. Semarang(ID): Universitas Diponegoro

Michael P. Todaro dan Stephen C. Smith. 2003. Pembangunan Ekonomi di Dunia. Ketiga. Jilid 1. Erlangga: Jakarta.

Nugroho, A, ST, MMSI (2002).Analisis Dan Perancangan Sistem Informasi Dengan Metodologi Berorientasi Objek. Bandung: Informatika Bandung.

Prasetyo, P. Eko. 2009. Fundamental Makro Ekonomi. Yogyakarta: Beta Offset

Pristina, Siestri.2013.Produk Domestik Regional Bruto (Pdrb), Inflasi Dan Belanja Daerah Pengaruhnya Terhadap Kesempatan Kerja Di Sulawesi Utara Tahun 2000-2012.Jurnal EMBA.(1):4:2206-2216.

Studi, P., Fakultas, A., \& Universitas, P. (2015). Pengaruh Penanaman Modal Dalam Negeri dan Penanaman Modal Asing Terhadap PDRB Sektor Pertanian di Provinsi Bali. 4(5), 307-316.
Unud, E. E. P. (2012). time series. 2013, 88-95.

Widodo, Tri. 2006. Perencanaan Pembangunan. Aplikasi Komputer (Era Otonomi Daerah). Yogyakarta: UUP STIM YKPN.

Zaris, R. 1987. Prespektif Daerah dalam Pembangunan Nasional. Jakarta, LPFE U 